\title{
WYCHOWANIE WE WSPOMAGANIU ROZWOJU CZŁOWIEKA SPRAWCZEGO. PRZESŁANKI TEORETYCZNE
}

\begin{abstract}
Abstrakt: W świetle analiz psychologów człowiek nie jest jedynie produktem przekazu genetycznego i kulturowego. Staje się aktywnym sprawcą, który podlega wprawdzie oddziaływaniu świata, ale również ów świat tworzy (Kozielecki 1999). Oznacza to, że człowiekowi przysługuje prawo do samodzielnego kształtowania własnej osobowości, do swobodnego rozwoju. We współczesnej globalnej rzeczywistości następuje koncentracja na indywidualności człowieka. W związku z tym powszechną praktyką stało się ześrodkowanie na indywidualizmie i psychologizmie jednostki, rozpowszechniła się „moda na myślenie i opisywanie rzeczywistości ludzkiej za pomocą kategorii «upodmiotawiania się», samorealizacji, indywidualizacji i autosterowności” (Błachnio 2011, s. 75). W poszukiwaniach optymalnego modelu wychowania, rozwijającego wspomniane właściwości, ważny wydaje się Model Obywatelskiej Współpracy, opracowany przez A. Brzezińską (2000, 2004). Jego charakterystyką jest trening upodmiotowienia, pozwalający zarówno na kształtowanie gotowości do rozwoju jednostki i jej otoczenia, jak też na samorealizację.
\end{abstract}

Słowa kluczowe: człowiek sprawczy, człowiek autorski, transgresje, model wychowania

\section{KSZTAŁTOWANIE SIĘ KONCEPCJI CZŁOWIEKA SPRAWCZEGO}

W stosunkowo krótkim czasie rozwoju psychologii jako nauki, podkreśla J. Kozielecki (2009), uczeni wypracowali na jej gruncie różnorodne i konkurencyjne sposoby myślenia o psychice i zachowaniu się człowieka. Obserwowana heterogeniczność poglądów nie jest przy tym cechą przejściową nauki, lecz stanowi w opinii wspomnianego psychologa stałą właściwość tej dyscypliny. Mimo że współcześnie dominującą rolę w badaniach odgrywają paradygmaty, takie jak: behawioryzm, 
psychoanaliza, kognitywizm, psychologia humanistyczna (Kozielecki 2000, 2009, s. 331), to wymienia się także inne ogólne sposoby myślenia, jak psychologia cech, psychologia topologiczna czy egzystencjalna. Nie sposób, dowodzi J. Kozielecki, pominąć zespołów przekonań powstających na gruncie rodzimej psychologii, jak transgresywizm czy koncepcja autorskiej osobowości (Obuchowski 1985, 1993, 2000; Kozielecki, 1987, 2001, 2009). Wskazane przesłanki czy teorie stanowią kontekst poznawczy i interpretacyjny natury oraz zachowania się człowieka, wzbogacają wiedzę humanistyczną, przez co ułatwiają zrozumienie problemów współczesnych ludzi, zwiększają swobodę wypracowania własnych poglądów, umożliwiają formułowanie autorskich systemów pojęć i konkretnych założeń badawczych (Kozielecki 2000, 2009).

W świetle analiz psychologów człowiek nie jest jedynie produktem przekazu genetycznego i kulturowego. Staje się aktywnym sprawcą, który podlega wprawdzie oddziaływaniu świata, ale również ów świat tworzy (Kozielecki 1999). Oznacza to, że człowiekowi przysługuje prawo do samodzielnego kształtowania własnej osobowości, do swobodnego rozwoju (Zeidler 2006, s. 73), prawo do realizacji siebie zgodnie $\mathrm{z}$ własnymi pragnieniami i wyobrażeniami. Idee te, co przypomina W. Zeidler, nie pojawiły się dopiero w XXI w. Spotyka się je już od czasów Arystotelesa, co skłania przywołanego psychologa do przypomnienia pojęcia entelechia. Określa ono tendencję i zdolność osoby do samorealizacji, która opiera się na dwóch najbardziej podstawowych właściwościach osoby: na jej zdolności do „samozachowania” oraz zdolności do „samorozwoju”. Niemniej archetyp człowieka jako układu realizującego się odpowiednio do założonego przez siebie samookreślenia, przyjmującego kształt samorealizatora, zmieniającego własne umiejętności przy nieograniczonych i tym samym nieprzewidywalnych potencjach, jest najmłodszym wzorem człowieka w historii kultury i cywilizacji (Obuchowski 2000, s. 76). Współczesny szybko zmieniający się świat wywołuje zmiany w samych ludziach, w ,ujmowaniu przez człowieka siebie, swojego sensu życia i wynikającej $\mathrm{z}$ tego indywidualnej odpowiedzialności: wykorzystania własnego umysłu i jego mocy twórczych” (Obuchowski 2001, s. 31). Zarysowuje się model osobowości, „nowego indywidualisty”, „otwartego indywidualisty” (tamże, s. 166), „człowieka autora”" (Obuchowski, Błachnio 2011). Osobowość staje się „narzędziem spełniania się rozwojowego w toku konstruowania kultury od siebie i dla siebie" (Obuchowski 2003, s. 66), a zaproponowana przez K. Obuchowskiego koncepcja osobowości autorskiej stanowi „systematycznie ulepszane narzędzie do opisu rzeczywistości, w której żyjemy" (Błachnio 2011, s. 11). Odzwierciedla relacje między osobą a jej

${ }^{1}$ W 2001 r. K. Obuchowski napisał, że rezygnuje z pojęcia „indywidualizm” ze względu na wieloznaczność definicyjną, co czyni dalsze posługiwanie się nim niepraktycznym (Obuchowski 2001, s. 166). 
otoczeniem (Obuchowski 2003, s. 66). Jednostka w pełni upodmiotowiona dokonuje samookreślenia, które „postrzega jako wartość samą w sobie. Poznanie siebie, właściwe zidentyfikowanie swoich pragnień i potrzeb są istotne dla osobistego rozwoju" (Błachnio 2011, s. 34). Dlatego dostrzega się dominację określonych właściwości człowieka-autora, takich jak podmiotowość, intencjonalność, sens życia i adaptacja twórcza (Obuchowski, Błachnio 2011, s. 167-171). Człowiek-autor to optymalna postać autonomii jednostki ludzkiej (Obuchowski 2000, s. 41-44), osoby wychodzącej poza zastane informacje, orientującej się na przyszłość, stąd podejmującej ryzyko „osobistego konstruowania wartościujących funkcji kultury na własny użytek oraz na własną odpowiedzialność” (tamże, s. 69).

Także J. Kozielecki uważa, że istota ludzka charakteryzuje się wewnątrzsterownością. W dużym stopniu decyduje o własnym losie. Nie jest zatem manipulowany - wbrew swojej woli - przez ślepe prawa historii, ponieważ nie ma takich praw (Kozielecki 2009, s. 331). Co więcej, sprawca nie tylko pragnie egzystować i przystosowywać się do otoczenia, ale nastawiony jest na rozwój swojego organizmu i psychiki oraz na wzbogacanie kultury i cywilizacji. Realizacji tego celu służą transgresje konstruktywne, tj. przekraczanie istniejącego stanu rzeczy w kierunku zdobywania czy tworzenia nowych wartości kształtujących osobowość i umysł, podnoszące dobrobyt i dobrostan (tamże). Przypisywana rodzajowi ludzkiemu umiejętność przekraczania granic swoich osiągnięć, niejako cecha atroficzna naszego gatunku, pozwala na kształtowanie jakościowo nowych form i zachowań, zwiększa możliwości poznawcze, poszerza wolność jednostki² (Kozielecki 1998, s. 11-14). Co prawda, powiada przywoływany autor, istoty ludzkie nie cechuje jednakowy stopień ekspansji czy innowacyjności, niemniej całkowite zaprzestanie działań transgresyjnych oznaczałoby stagnację czy wręcz zanik ludzkiego świata. Stąd też psycholog konstatuje: „Człowiek - jako gatunek - będzie transgresyjny albo nie będzie go wcale" (tamże, s. 12).

Przypomniane obserwacje i opinie uprawniają do stwierdzenia, że rozpoczął się "proces zmiany samookreślenia” osoby (Obuchowski 2000, s. 22), proces „rosnącej autonomizacji człowieka wobec zewnętrznego świata" (Błachnio 2011, s. 31). Jego konsekwencją, ściśle powiązaną z przemianami cywilizacji, stała się nowa pozycja jednostki ludzkiej, której istotą jest przystosowanie świata do siebie, do własnych wymagań, a nawet tworzenie przez osobę tych wymagań zgodnie z prywatną koncepcją świata i siebie samej w tym świecie (Obuchowski 2001, s. 161). W ten sposób wyłoniła się nowa konfiguracja właściwości człowieka, który pokonał kolejny etap długiej drogi zyskiwania autonomii, wiodącej od uprzedmiotowionej

2 „Wolność to potencjalna transgresja, a transgresja to zrealizowana wolność” (J. Kozielecki 1998, s. 12). 
postaci jednostki ludzkiej, utożsamiającej się z przypisywanymi jej rolami, przez pozycję przedmiotu świadomego własnej odrębności i swoistych właściwości, do człowieka kreującego siebie jako osobę (tamże, s. 167).

Liczne koncepcje osobowości człowieka, przypomina M. Jarymowicz, funkcjonujące w polskiej literaturze przedmiotu, opisują istotę ludzką jako osobę inicjującą, aktywną, „transgresyjną”, otwartą na świat (Tomaszewski, Reykowski, Obuchowski, Kozielecki, za: Jarymowicz 2008, s. 9). Wyniki prowadzonych badań skłaniają zaś do refleksji nad dojrzewaniem człowieka ku podmiotowości (tamże). Błachnio A. konstatuje, że powszechną praktyką w globalnej rzeczywistości stało się ześrodkowanie na indywidualizmie i psychologizmie jednostki, rozpowszechniła się „moda na myślenie i opisywanie rzeczywistości ludzkiej za pomocą kategorii «upodmiotowiania się», samorealizacji, indywidualizacji i autosterowności” (Błachnio 2011, s. 75). „W fazie globalizacji pytanie o to, czym jestem jako osoba, przekształca się w pytanie, jakie są rezerwy moich możliwości, jakimi siłami napędowymi dysponuję w tej rzeczywistości, która mi pozostała do dyspozycji" (Obuchowski 2009, s. 203).

Akceptacja uwydatnionych właśnie prawidłowości rozwojowych oznacza, że psycholog, nauczyciel czy wychowawca „coraz częściej i coraz bardziej systematycznie traci swój patent na formowanie cudzych osobowości" (Zeidler 2006, s. 73). Powszechnie przyjmuje się, że nie sposób wymodelować człowieka, a istotną i pierwszoplanową kwestią staje się poznanie i pełne wykorzystanie aktualnych, osobistych potencji rozwoju i samorozwoju (Kozielecki 1998, s. 27; zob. też Kozielecki 1999, s. 113-127). „Są podstawy empiryczne, aby uznać go [człowieka - przyp. autorki] za współprzyczynę zdarzeń, za sprawcę współodpowiedzialnego za swoje czyny [...]” (tamże, s. 136). „Badacze dyskutują wobec tego zakres faktycznego sprawstwa jednostki" (Błachnio 2011, s. 72).

\section{CZŁOWIEK SPRAWCZY A ROZWÓJ}

Zatem ku czemu zmierza rozwój osoby? Ogólna odpowiedź, powołując się na opinię A. Brzezińskiej, może brzmieć tak: „Rozwój zmierza ku większemu zróżnicowaniu, ku większemu uporządkowaniu i lepszej integracji, co w rezultacie daje wzrastającą samodzielność w zaspokajaniu potrzeb istotnych w kolejnych okresach życia” (Brzezińska 2000, s. 65). To, czego dotyczy zróżnicowanie, porządkowanie i integracja, co oznacza pojęcie samodzielność, które potrzeby uznane zostaną za istotne w danym okresie życia - to wszystko zależy od koncepcji teoretycznej przyjętej przez badacza (tamże, s. 65). Anna Brzezińska wybiera w ten sposób perspektywę dynamicznego interakcjonizmu (tamże). Konsekwencją takiego spojrzenia 
jest teza określająca rozwój jako wynik wymiany, która zachodzi pomiędzy jednostką a jej otoczeniem (a zwłaszcza wymiany między jednostką a innymi ludź$\mathrm{mi})$. Zatem efekty rozwoju nie są powiązane jedynie z potencjałem jednostki, ale w znaczącym stopniu również z potencjałem otoczenia. Rozważając rozwój jednostki ludzkiej, należy więc brać pod uwagę także ukierunkowane działania, które są podejmowane przez ludzi w ich otoczeniu. W literaturze przedmiotu powtarza się stwierdzenie, że podejmowane przez jednostkę działania mogą służyć różnym celom. Przywoływana psycholog przypomina koncepcję rozwoju osobowości poprzez zadania dalekie, rozwiniętą przez K. Obuchowskiego. Uczony wskazuje, że rzeczywisty rozwój osobowości można w zasadzie opisać jako „produkt uboczny działalności człowieka” (tamże, s. 65). Nie może być on bowiem celem samym w sobie, gdyż wtedy nie nastąpią zmiany rozwojowe, lecz - nazwane przez K. Obuchowskiego - naturalne albo neurotyczne. Nie można przy tym zapominać, że działania podejmowane przez ludzi w otoczeniu jednostki mają różnorodne cele. Ta świadomość jest istotna dla analizowania biegu rozwoju oraz organizacji procesu intencjonalnego wychowania. Należy podkreślić, że rozwój osoby nie jest celem, lecz procesem rozciągniętym w czasie, który biegnie i stopniowo manifestuje się kolejnymi osiągnięciami ${ }^{3}$. Proces samorealizacji jednostki opisywany jest jako proces zmian rozwojowych, które bazują na realizacji zadań dalekich. Zatem samorealizacji nie wolno utożsamiać $\mathrm{z}$ procesem „kreacji zawartego w osobie potencjału danej formy" (tamże, s. 34). Polega raczej na osiągnięciu kształtów optymalnych, uwzględniających dwa ważne konteksty - możliwości osoby jak i interesy świata, w którym żyje (Obuchowski, za: Brzezińska 2004, s. 34). Istota wychowania sprzyjającego rozwojowi tkwi w organizowaniu sytuacji, w których jednostka podejmuje różnorodne w swojej istocie zadania, oraz we wspieraniu osoby w realizacji zamierzeń.

Józef Kozielecki przekonuje zaś, że jeśli ujmuje się człowieka jako samodzielny byt sprawczy obdarzony wolnością wyboru i samosterowny, to zarazem przyjmuje się, że wewnętrzne motywacje decydują o kierunku działań i osiąganych celach (Kozielecki 2001, s. 242). Człowiek jako smodzielny sprawca wykonuje dwa

\footnotetext{
${ }^{3}$ Rozwój dokonuje się w oparciu o mechanizm adaptacji twórczej. Sprowadza się on do aktywnego wybiegania w przyszłość, intencjonalnego i dobrowolnego obierania w niej elementów, których realizacja ma zapewnić poczuce sukcesu, spełnienia i stałość kierunku samorozwoju człowieka (Obuchowski, Błachnio 2011, s. 170). Warunkiem niezbędnym realizacji mechanizmu adaptacji twórczej jest tworzenie prywatnej wiedzy i organizacji własnych zadań za pomocą abstrakcyjnych i dynamicznie modyfikujących swoje znaczenie kategorii. Tym samym wyklucza to „[...] tendencje do unifikacji i stabilizacji biegu życia ludzi, a w zamian preferuje się coraz wyraźniej i dalej postępującą indywidualizację" (tamże, s. 171). Decyzja o rozwoju, o wyborze zadań bliskich czy dalekich, to zadanie układu programującego, tranzytywnego, relacyjnego - interakcyjnego, pośredniczącego między jednostką a otoczeniem.
} 
rodzaje działań/ zadań: ochronne i transgresyjne. Ochronne, w znaczeniu zachowawczych czy adaptacyjnych, prowadzą do zaspokajania potrzeb podstawowych (tamże, 242). Działania transgresyjne oznaczają z kolei wychodzenie poza granice własnych możliwości, co w rezultacie prowadzi do przekroczenia siebie.

Realizacja samego siebie okazuje się w teorii Obuchowskiego zarówno możliwością ustosunkowania się do siebie i świata, jak i koniecznością w świecie podlegającym nieustannym metamorfozom. Uczony wskazuje więc na potrzebę wychodzenia poza relacje zachodzące pomiędzy jednostką a otoczeniem, co wiąże się z koniecznością ustosunkowania się do przemian, którym podlega świat (Obuchowski 1993, s. 37). Dlatego przywołany wcześniej człowiek-autor postrzega siebie jako źródło swojego postępowania, cele własne jako przedmiot swoich intencji, a świat wokół jako szanse spełniania się (Obuchowski 2000, s. 104). Obserwowana i pokrótce zreferowana ewolucja koncepcji próbujących określić właściwości człowieka dowodzi nie tylko zwiększenia stopnia swobody, uwalniania człowieka z zależności od innych ludzi, ale i zwiększenia odpowiedzialności za siebie i za swoje działania wobec świata (Obuchowski 2001, s. 164).

\section{MODEL WYCHOWANIA JAKO KONTEKST ROZWOJU CZŁOWIEKA-SPRAWCY}

Józef Kozielecki stawia tezę, że najbardziej humanistyczną i subiektywnie najbardziej przyjemną strategią ulepszania człowieka jest strategia samorozwoju (Kozielecki 1999, s. 126). Jeśli człowiek jest podmiotem, bytem sprawczym, którego charakteryzuje wewnątrzsterowność, poczucie skuteczności, autonomii i tożsamości, to w sposób naturalny nastawiony jest na rozwój swojego organizmu oraz na wzbogacanie kultury i cywilizacji (Kozielecki 2009, s. 336.). Wspomniana strategia wynika z przyjęcia twierdzenia o człowieku jako aktywnym sprawcy, ulegającemu oddziaływaniom świata, ale zarazem ten świat tworzącemu. Podobnie M. Ledzińska dostrzega znaczenie strategii samorozwoju, ponieważ tylko taka jednostka, która podejmuje trud ustosunkowania się do samego siebie i otaczającej rzeczywistości, może umiejętnie radzić sobie z napotykanymi zmianami, podnosząc jednocześnie poziom własnej egzystencji (Ledzińska 2005; zob. też Błachnio 2011, s. 44).

Galloway Ch. (1988, za Bazel 1999) pisał: „Procesy poznawania samego siebie oraz reguł obowiązujących w danej społeczności znane są jako socjalizacja, natomiast sekwencję rozwojową, w której to uczenie się zachodzi, określamy mianem rozwoju osobowo-społecznego". Rozwój ten jest organizowany i kontrolowany w placówkach edukacyjnych. Od tego, jaki styl wychowania i kształcenia będą 
preferować nauczyciele, oraz od sposobu interpretacji planów i programu nauczania, dokonywanej w działalności edukacyjnej, będzie zależeć sposób socjalizacji dzieci (tamże). Niestety, w szkole masowej zmiany programowe stają się celem samym w sobie, zamiast służyć rozwojowi osobowości (Brzezińska 2004, s. 33). W tej sytuacji jednostka zaczyna coraz bardziej bezwolnie podporządkowywać się stawianym z zewnątrz wymaganiom. W ten sposób uruchamia się proces zmian naturalnych albo postępuje proces nueurotyzacji osobowości (tamże, s. 33). Szkołę (w tym zwłaszcza szkołę podstawową) można zatem nazwać za K. Obuchowskim „nienaruszalnym rezerwatem kultury ludzi-przedmiotów”, w którym każde dziecko przechodzi trening uprzedmiotowienia (Obuchowski 1993, s. 38). Odbywa się on w szkole o orientacji adaptacyjnej, kształcącej zachowawczo, gdzie przekazuje się uczniom gotową wiedzę o świecie po to, aby można ją było reprodukować we właściwym czasie, co pozwalałoby na przystosowanie jednostki do zastanej rzeczywistości. W efekcie zarysowanego oddziaływania szkoły absolwent jest człowiekiem jednowymiarowym, a nie pełnowymiarowym, cechuje go orientacja zachowawcza zamiast pożądanej transgresyjnej. Opisane zjawiska upoważniają do stwierdzenia, za Kozieleckim (1998, s. 32-38), że współczesny system edukacyjny kształci człowieka oświeconego, a nie innowacyjnego. Postulowany model edukacyjny to kształcenie człowieka sprawcy. Powinien on służyć kształtowaniu umiejętności aktualizacji i wykorzystania własnych, wrodzonych potencji osoby; umożliwić zdobycie wiedzy o swoich zaletach i wadach, aby zamienić to, co potencjalne, w to, co realne; aby aktualizować własny potencjał i go rozwijać (Kozielecki 1999, s. 125), tworzyć siebie, swoją osobowość, według własnego projektu (tamże). Wspomniany model J. Kozielecki proponuje wesprzeć i osadzić na następujących założeniach:

Kształcenie postawy badawczej człowieka, w znaczeniu „trwałej tendencji do poszukiwania problemów w świecie i do samodzielnego ich przezwyciężania” (Kozielecki 1998, s. 39), urasta do rangi zasadniczego celu procesu kształcenia innowacyjnego. Sformułowanie i przyjęcie tak rozumianego celu wynika z potrzeby odczytywania przez człowieka innowacyjnego świata. Stanowi on, jak stwierdza uczony, obszar wątpliwości poznawczej i niepewności wykonawczej, który trzeba zinterpretować i zrozumieć na drodze poszukiwania odpowiedzi na pojawiające się nieustannie pytania, racjonalnego pokonywania trudności, rozstrzygania/zachowania się w sytuacjach nowych czy nieprzewidzianych. Postawa badawcza ułatwia wykrywanie problemów i ich rozwiązywanie.

Proces zdobywania wiedzy o świecie i sobie samym powinien zachodzić w sposób naturalny, w toku gromadzenia, budowania osobistego doświadczenia, w bezpośrednim kontakcie z poznawaną rzeczywistością, w wyniku podejmowanej nad nią refleksji. Budowaniu wiedzy służy konfrontacja z problemami dywergencyjnymi, których przezwyciężanie rozwija pomysłowość i fantazję, ogranicza 
przekaz, umożliwia budowanie wiedzy typu: wiem jak, aktywizuje pracę obu półkul mózgowych.

Opisany wyżej sposób zdobywania/budowania wiedzy ułatwia jej strukturalizację w postaci schematów lub metaschematów, a nie liniowych, zatomizowanych czy rozproszonych układów.

W wyniku podejmowania aktywności badawczej uczeń zdobywa pozycję sprawcy, staje się zatem podmiotem, inicjuje działania, dokonuje wyborów, ponosi ich konsekwencje.

Nowy model kształcenia cechuje „orientacja prospektywna, z zakładaną adaptacją kreatywną, z przyjmowanym przygotowaniem do podejmowania mądrych innowacji, z kształtowaniem umiejętności alternatywnego, dywergencyjnego, probabilistycznego i globalnego myślenia, z upowszechnianiem sztuki dokonywania wyborów, zwiększania «uporu realizacyjnego»" (Kozielecki 1998, s. 44-45, 138), zgody na zwiększenie nakładów czasu i energii.

Urzeczywistnienie wizji kształcenia innowacyjnego, wedle zapewnień J. Kozieleckiego (tamże, s. 42), zapobiegnie deprawacji potencjału rozwojowego oraz dezindywidualizacji. Ponadto umożliwi przejawianie postaw sprawczych, aktywnych, wykształci kontrolę emocjonalną i odpowiedzialność moralną, wzmocni poczucie godności, zbliży do ideału „wszechstronnie rozwiniętej osobowości” (tamże, s. 42-43).

Zakładając, że misją szkoły ma stać się wzbogacanie zdolności jednostki do stawania się podmiotem własnego działania (Dylak 2009), osobisty rozwój i ekspresja własnego ja, zdaniem Batesa, są możliwe w szkole, która stanie się siecią komunikacji; umożliwi budowanie własnej tożsamość uczniów w kontekście komunikowania się z innymi i konstruowania nowych form bycia razem (tamże, s. 34); w szkole kształtującej sposób życia w bogatym świecie wartości (tamże, s. 30). Działania wychowawcze powinny osadzać się na pomocy człowiekowi, aby umiał samodzielnie wytworzyć sobie pogląd na jakiś temat, potrafił go zmienić $\mathrm{w}$ wyniku negocjacji ze światem lub z innymi ludźmi, wiedział, jak pomóc innym ludziom, aby „sami potrafili zbudować własny gmach przekonań obok stereotypów" (Obuchowski 2000, s. 36).

Anna Brzezińska $(2000,2004)$ dokonała analizy czterech modeli wychowania, wynikających z odmiennych psychologicznych koncepcji człowieka. Brała pod uwagę kryterium preferowanej wartości ukierunkowującej wychowanie i cele, na które w sposób jawny skierowane jest wychowanie (2000, s. 245). 
Tab. 1. Psychologiczne koncepcje człowieka a wizje wychowania

\begin{tabular}{|l|l|l|l|}
\hline Model & $\begin{array}{c}\text { Naczelna } \\
\text { wartość }\end{array}$ & Wizja wychowania & \multicolumn{1}{|c|}{$\begin{array}{c}\text { Obszar oddziaływań i rodzaje } \\
\text { działań wychowawczych }\end{array}$} \\
\hline I & $\begin{array}{l}\text { Obywatelska } \\
\text { współpraca }\end{array}$ & $\begin{array}{l}\text { Zmiana relacji osoba- } \\
\text {-otoczenie }\end{array}$ & $\begin{array}{l}\text { Miejsce w społeczeństwie - wspieranie } \\
\text { poszukiwania i tworzenia przez osobę } \\
\text { miejsca w społeczeństwie }\end{array}$ \\
\hline II & $\begin{array}{l}\text { Produktywna } \\
\text { niezależność }\end{array}$ & Zmiana osobowości \\
jednostki & $\begin{array}{l}\text { Zdrowie psychiczne - tworzenie kontek- } \\
\text { stu dla zdrowia psychicznego oraz wspie- } \\
\text { ranie u osoby gotowości i umiejętności sa- } \\
\text { morealizacji }\end{array}$ \\
\hline III & $\begin{array}{l}\text { Krytyczne } \\
\text { myślenie }\end{array}$ & $\begin{array}{l}\text { Zmiana struktur po- } \\
\text { znawczych jednostki }\end{array}$ & $\begin{array}{l}\text { Krytyczny umysł - wzbogacanie wiedzy } \\
\text { o sobie, otoczeniu, świecie, kształtowa- } \\
\text { nie i doskonalenie zdolności umysłowych }\end{array}$ \\
\hline IV & $\begin{array}{l}\text { Bogactwo } \\
\text { repertuaru } \\
\text { zachowań }\end{array}$ & $\begin{array}{l}\text { Zmiana systemu za- } \\
\text { chowania jednostki }\end{array}$ & $\begin{array}{l}\text { Adekwatne zachowanie - kształtowanie } \\
\text { i doskonalenie umiejętności, kształtowa- } \\
\text { nie nawyków, rozwijanie samokontroli }\end{array}$ \\
\hline
\end{tabular}

Źródło: A. Brzezińska 2000, s. 245, tabela 48.1

W poszukiwaniach optymalnego modelu wychowania, w którym istotnym elementem jest trening upodmiotowienia, pozwalający zarówno na kształtowanie gotowości do rozwoju jednostki i jej otoczenia, jak też na samorealizację, ważny wydaje się model I - Obywatelskiej Współpracy (tab. 1). Najistotniejszym argumentem przemawiającym za tym wyborem jest współpraca osoby z innymi jako naczelna wartość, którą sytuuje się w nim na czele hierarchii. Rozwój następuje bowiem tylko wśród ludzi i dzięki nim (Brzezińska, 2005, s. 7). Przyjmując inny motyw wyboru wspomnianego modelu, praca w nim oznacza uwrażliwienie na interes szerszy niż tylko jednostkowy czy grupowy. Jednocześnie za sprawą tak interpretowanego modelu wychowania realizowany jest ważny cel, jakim jest zmiana relacji między osobą a jej otoczeniem (Brzezińska 2000, s. 246-247). W warunkach modelu I ważne jest niekonfliktowe współistnienie, realizowanie zarówno potrzeb jednostki, jak i potrzeb społecznych, co nie prowadzi do sytuacji konfliktowych (indywidualizm czy wspólnotowość). Warto w tym miejscu podkreślić, że kształcenie kooperacyjne wspomaga rozwój indywidualnych kompetencji intelektualnych Na przykład, podaje A. Brzezińska, rozwiązywanie problemów w grupie wiąże się z koniecznością uzgadniania założeń, podejmowania wspólnych/kompromisowych decyzji jak też skorelowania rytmu działań jednostki i grupy, dostosowania rytmu działania do rytmu partnerów. Kształcenie we współpracy daje również sposobność do rozwoju jednostkowych kompetencji społecznych, takich jak: komunikowania się, nawiązywania i podtrzymywania kontaktu, organizowania pracy, kierowania innymi lub podporządkowania się kierownictwu itp. (tamże, s. 247). 
Cytowana autorka uznaje opisany model I za najszerszy. Pozwala on na nieograniczoną perspektywę ujmowania celów kształcenia i wychowania (podejmowane przez nauczyciela działania i ich konsekwencje nastawione są na przyszłość, ale uwzględniają kontekst tu i teraz), a, co równie ważne, wyznacza wizję wychowania w odniesieniu do obszaru osoba i jej środowisko lokalne oraz społeczeństwo (Brzezińska 2000, s. 247; 2004, s. 34). Przywołując raz jeszcze kluczową tu tezę K. Obuchowskiego o szybko zmieniającym się świecie jako kontekście zmian samych ludzi, analiza prac wspomnianego psychologa wskazuje na kierunek owych zmian. „Ich istotą jest uformowanie osobowości sprzyjającej zadowoleniu z życia wówczas, gdy realizowane jest dobro społeczne. Akcent pada tu na wszechstronny rozwój, którego warunkiem jest samorealizacja. Rozwój ten jest wynikiem adaptacji twórczej jednostki do zadań [...]”. W modelu Obywatelskiej Współpracy, posługując się terminologią K. Obuchowskiego, nauczyciel stara się organizować właśnie zadania rozwojowe/zadania dalekie. Posiłkując się natomiast określeniami J. Kozieleckiego, wychowawca organizuje warunki do przejawiania działań transgresyjnych. Wychowanie wspiera wówczas poszukiwanie i tworzenie własnego miejsca w społeczeństwie. Przecież podejmowane przez uczniów działania transgresyjne, skierowane „ku rzeczom”, „ku ludziom”, „ku symbolom” i „ku sobie”, pełnią w życiu człowieka dwojaka rolę. Po pierwsze, pozwalają potwierdzić i zaspokoić pragnienie własnej wartości, przez co wywołują dumę i nadają sens życiu. Z drugiej strony, co jest szczególnie doniosłe ze społecznego punktu widzenia, dzięki przekraczaniu siebie rozwija się technika, nauka, organizacja, sztuka, możliwy staje się postęp cywilizacyjny (Kozielecki 1998, s. 62). Informacje o sobie samym, o swojej osobowości, o systemie wartości czy też o dojrzałości emocjonalnej, w dużym stopniu regulują kontakty $\mathrm{z}$ innymi ludźmi, stają się mediatorem w nieustającej wymianie informacji społecznych (tamże, s. 241). Wychowanie i kształcenie obywatelskie (tab. 1) prowadzą do efektów zoperacjonalizowanych przez A. Brzezińską jako: poszanowanie godności człowieka, akceptacja idei pluralizmu, poczucie przynależności do diad, grup czy wspólnot, poczucie solidarności z innymi, gotowość do podejmowania wyzwań, różne kompetencje społeczne, wiedza o funkcjonowaniu społeczeństwa (Brzezińska 2004, s. 64).

Każdy człowiek, jak podkreśla M. Kielar-Turska (1992, s. 12-13), stopniowo odkrywa siebie, oznacza to, że poznaje swoje zdolności, właściwości, upodobania i dąży do ich realizowania oraz wykorzystywania. Warto więc uczyć ludzi, jak aktualizować i w pełni wykorzystywać wrodzone potencje fizyczne, intelektualne i motywacyjne, jak tworzyć samego siebie w czasach megarewolucji technicznej. „Trzeba zatem próbować wykorzystać swoje wrodzone możliwości i talenty, a gdy metoda samorozwoju nie da wyników, przejść do innych strategii, takich jak procedury kulturyzacji [...]” (Kozielecki 1999, s. 127). Problem kształcenia człowieka 
wydobywającego swój potencjał rozwojowy polega na tym, że „nie udało się dotychczas znaleźć dla niego realnej alternatywy. Wiele paradygmatów i wizji kształcenia - mimo ich oryginalności - nie spełnia aspiracji społecznych i trudno je wcielić w życie. Żyjemy w czasach luki edukacyjnej, w których pewien system się przeżył, a drugi się nie narodził. Jest to jeden z najważniejszych dylematów epoki" (Kozielecki 1998, s. 48). Jednocześnie przywoływany psycholog jest przekonany, że w zakresie tak złożonych i wielopłaszczyznowych problemów, jak kształcenie nowego pokolenia, trudno byłoby znaleźć rozwiązania optymalne. Należy raczej, sugeruje on, zadowolić się projektami dobrymi, zgodnymi z aspiracjami społecznymi. Co więcej, każda wizja edukacji, która pozwoli zminimalizować, a wręcz zapobiegnie zjawisku nudy i lęku (tamże, s. 49), jest godna uwagi i zainteresowania. Ponadto wyznaczanie koniecznego modelu nie wymaga, przekonuje J. Kozielecki, rewolucji w systemie edukacyjnym, nie burzy jego podstaw, a nawiązuje do najlepszych tradycji oświatowych, postulując stymulowanie wielostronnego rozwoju osobowości z natury gotowej na rozwój (Kozielecki 2001, s. 274). Poszukiwania warunków indywidualnego, swobodnego rozwoju być może lokują się w zakresie pedagogiki przejścia (Kwieciński 2012), czyli budowania nowego rozwiązania „na drodze przechodzenia od strategii restrykcji, przez centralne reformy oświaty do strategii subsydiarności - to jest do rozsianych, oddolnych, wyspowych, organicznych inicjatyw w różnej skali, od monopolu do wielogłosowości” (tamże, s. 24).

\section{LITERATURA}

Bazel M. (1999). Dominacja funkcji socjalizacyjnej, „Edukacja i Dialog” 1 (dostęp: 25.11.2013).

Błachnio A. (2011). Człowiek autorski w erze globalizacji. Wydawnictwo Uczelniane Akademii Bydgoskiej im. Kazimierza Wielkiego, Bydgoszcz.

Brzezińska A. (2000). Psychologia wychowania. W: J. Strelau (red.). Psychologia. Podręcznik akademicki. T. 3: Jednostka w społeczeństwie i elementy psychologii stosowanej. GWP, Gdańsk.

Brzezińska A. (2004). Społeczna psychologia rozwoju. Wydawnictwo Naukowe Scholar, Warszawa,

Dylak S. (2009). Przekazywanie wiedzy - szkolnym rytuałem. W: K. Kusiak, I. Nowakowska-Buryła, R. Stawinoga (red.). Edukacyjne konteksty rozwoju dziecka $w$ wieku wczesnoszkolnym. Wydawnictwo UMCS, Lublin.

Jarymowicz M. (2008). Psychologiczne podstawy podmiotowości. Wydawnictwo Naukowe PWN, Warszawa. 
Kielar-Turska M. (1992). Jak pomagać dziecku w poznawaniu świata. WSiP, Warszawa.

Kozielecki J. (1998). Człowiek wielowymiarowy. Wydawnictwo Akademickie Żak, Warszawa.

Kozielecki J. (1999). Transgresje jako źródło kultury. W: J. Kozielecki (red.). Humanistyka przełomu wieków. Wydawnictwo Akademickie „Żak”, Warszawa.

Kozielecki J. (2000). Koncepcje psychologiczne człowieka. Wydawnictwo Akademickie „Żak”, Warszawa.

Kozielecki J. (2001). Psychotransgresjonizm, Nowy kierunek psychologii. Wydawnictwo Akademickie „Żak”, Warszawa.

Kozielecki J. (2009). Psychotransgresjonizm - zarys nowego paradygmatu. W: J. Kozielecki (red.). Nowe idee w psychologii. Psychologia XXI wieku. GWP, Gdańsk.

KozieleckiJ. (1999). Koncepcja transgresyjna człowieka: analiza psychologiczna. PWN, Warszawa.

Kwieciński Z. (2012). Pedagogie postu. Preteksty. Konteksty. Podteksty. Oficyna Wydawnicza „Impuls”, Kraków.

Ledzińska M. (2005). Zadania psychologa $w$ dobie techno polu. W: M. Ledzińska, G. Rutkowska, L. Wrona (red.). Psychologia współczesna: oczekiwania i rzeczywistość. Wydawnictwo Naukowe Akademii Pedagogicznej, Kraków.

Obuchowski K. (1985). Adaptacja twórcza. Książka i Wiedza, Warszawa.

Obuchowski K. (1993). Człowiek intencjonalny. Wydawnictwo Naukowe PWN, Warszawa.

Obuchowski K. (2000). Od przedmiotu do podmiotu. Wydawnictwo Uczelniane Akademii Bydgoskiej im. Kazimierza Wielkiego, Bydgoszcz.

Obuchowski K. (2001). W poszukiwaniu właściwości człowieka. OW Garmond, Poznań.

Obuchowski K. (2009). Refleksje autobiograficzne psychologa. Akademia Humanistyczno-Ekonomiczna w Łodzi, Łódź.

Obuchowski K., Błachnio A. (2011). Teoria osobowości autorskiej i kwestionariusz POA. W: W. Zeidler (red.). Kwestionariusze w psychologii. Postępy, zastosowania, problemy. Vizja Press\&It, Warszawa.

Ożarowski W. (2011). Ustalenie przydatności Popperowskiej zasady falsyfikacji do oceny koncepcji osobowości autorskiej. „Horyzonty Psychologii” t. I, nr 1, s. 101-126.

Zeidler W. (2006). Osobowość autorska jako Autopoiesis. „Polskie Forum Psychologiczne" t. 11, nr 1, s. 58-78. 


\title{
EDUCATION SUPPORTING THE DEVELOPMENT OF \\ AUTONOMOUS MAN THEORETICAL CONSIDERATIONS
}

\begin{abstract}
In the light of recent studies by psychologists, a human is not only a product of genetic and cultural transmission. S/he becomes an active person, an author, who is a subject of the influence of the world, but who also creates this world (Kozielecki 1999). This means that a human has the right to form his/her own personality, as well as the right to develop freely. A common practice in contemporary global reality has become to center upon individuality and upon characteristics of the inner self of man. Consequently, the approach to thinking and describing human life by categories: becoming a subject of one's own life, self-realization, individualization has spread recently. Thus, the educational process should be focused on a human being, understood as an autonomous entity, which gradually discovers itself (Błachnio 2011, s. 75). In the search for the optimal model of education, the model of Civic Cooperation developed by A. Brzezińska (2000, 2004), appears to be significant. An important element of the abovementioned model is training of subjectivity, which makes possible both: the formation of readiness for the personal and environmental development, and self-realization.
\end{abstract}

Key words: autonomous men, the self-authoring men, transgressions, model of education 